\title{
Does CEO Characteristics Play Important Role on Malaysian Firms' Environmental Disclosure?
}

\author{
Mohd Waliuddin Mohd Razali (Universiti Malaysia Sarawak)* \\ Fathilla Ashikin Binti Roslanie (Universiti Malaysia Sarawak) \\ Rayenda Khresna Brahmana (Universiti Malaysia Sarawak) \\ Sharifah Sabrina Syed Ali(Universiti Malaysia Sarawak)
}

\begin{abstract}
The objective of this study is to examine the relationship between company environmental disclosures and CEO characteristics in term of tenure and education background such as MBA (Master in Business Administration) and legal background. Sample data collected from annual reports of companies listed in Bursa Malaysia in financial year end as 31st December consist 74 companies listed in Malaysia with various sector and in years from 2011 till 2013. The result shows that CEO's tenure and CEO with legal education have negative relationship with the environmental disclosure. Only one of controlling variables which is size has positive relationship with environmental disclosure. The study concludes that CEO whohas work long in the company tents and CEO with legal background may have less willingness to take risk to disclosure environmental information.
\end{abstract}

\section{Board Independence and Liquidity: Evidence from East Asian Countries}

\author{
Ebrahim Bazrafshan (Universiti Sains Malaysia)* \\ Chee-Wooi Hooy (Universiti Sains Malaysia)
}

\begin{abstract}
We investigate the link between board composition and liquidity of a firm's shares using a sample of East Asia companies. On average, greater board independence significantly increases liquidity. However, that relation is mediated by several other variables that influence the flow of information from managers to the board and the public. The beneficial impact of board independence on liquidity is reduced when more information-independent brokers make a market in shares, when board-management relations are strained, or when CEOs have greater bargaining power relative to the board. While legal environments that provide greater investor protections tend to increase liquidity, they do not appear to meaningfully affect the impact of board independence.
\end{abstract}

\section{The Performance of Politically Connected Firms in Malaysia}

Wai-Yan Wong (Universiti Sains Malaysia)*

Chee-Wooi Hooy (Universiti Sains Malaysia)

\begin{abstract}
This study examines the relationshipbetween political connection and firm's performance of listed firms in Bursa Malaysia from 2002 to 2012. Specifically, we also test whether different types of connection yield different results.Past literatures on political rent-seeking presented mixed evidence that cost of political connection mayoutweigh the benefits. Overall, our study lends support to existing literatures that politically connected firms enjoys greater firm performance compared to non-connected firms. Besides that, result of this study indicates that government-linked companies have the best accounting performance among politically connected firms. We also found a surprising finding,that firm which is connected through family members of leading politician has the worst performance among connected firms.
\end{abstract}

